\title{
The Antibacterial Effect of Ethanol Extract of Garlic (Allium sativum L.) on Methicillin Resistant Staphylococcus aureus (MRSA) In Vitro
}

\author{
Utami Meilanie Putri ${ }^{1}$, Maftuchah Rochmanti ${ }^{2}$, Manik Retno Wahyunitisari ${ }^{3}$, Rebekah J. Setiabudi ${ }^{4}$ \\ ${ }^{1}$ Student, Faculty of Medicine, Universitas Airlangga, Surabaya, Indonesia, ${ }^{2}$ Lecturer, Department of \\ Pharmacology, Faculty of Medicine, Universitas Airlangga, Surabaya, Indonesia, ${ }^{3}$ Lecturer, Department of \\ Medical Microbiology, Faculty of Medicine, Universitas Airlangga, Surabaya, Indonesia, ${ }^{4}$ Lecturer, Department of \\ Medical Microbiology, Faculty of Medicine, Universitas Airlangga, Surabaya, Indonesia
}

\begin{abstract}
Objective: To determine the antibacterial activity of ethanol extract of garlic against Methicillin-Resistant Staphylococcus aureus. Method: Dilution test was performed on 9 different concentration of ethanol extract of garlic $(1024,512,256,128,64,32,16,8,4 \mathrm{mg} / \mathrm{mL})$ dissolved in DMSO 10\% and MRSA suspension on Mueller Hinton broth medium to determine the Minimum Inhibitory Concentration. The Minimum Bactericidal Concentration was determined by the result of streaking of MRSA inoculation on the nutrient agar plate. Results: The observation through Mueller Hinton broth medium has shown turbidity both before and after incubation because of garlic ethanol extract color which is blackish-brown and thick, while in the nutrient agar medium, MRSA bacteria grew on the media with concentrations $4,8,16,32,64$, \& $128 \mathrm{mg} /$ $\mathrm{mL}$ and unable to grow at concentrations of 256, 512, and $1024 \mathrm{mg} / \mathrm{mL}$. Conclusion: The MIC of ethanol extract of garlic on MRSA could not be determined, and the MBC in this study was $256 \mathrm{mg} / \mathrm{mL}$.
\end{abstract}

Keywords: Allium sativum, Methicillin Resistant Staphylococcus aureus, antibacterial activity.

\section{Introduction}

Antibiotic resistance is a major problem and threat to public health. CDC reports at least 2 million United States citizens are infected with antibiotic-resistant bacteria each year, and 23 thousand of them $\operatorname{died}^{1}$. One of the bacteria known for its resistance is MethicillinResistant Staphylococcus aureus. Staphylococcus aureus is a Gram-positive opportunistic bacteria that live as normal flora of the skin and nose but can be pathogenic in some people with weakened immune systems ${ }^{2}$. The main transmission of Staphylococcus infection occurs due to direct contact with human lesions, objects contaminated with human lesions, respiratory tract, and human $\operatorname{skin}^{3}$. Penicillin and $\beta$-lactam resistance in Staphylococcus aureus is caused by modification of

\section{Corresponding author:}

Maftuchah Rochmanti

Email: maftuchah-r@fk.unair.ac.id the penicillin-binding protein ${ }^{4}$. A study on 643 patients conducted at Dr. Soetomo Hospital Surabaya proved that $8.1 \%$ of them were detected as carriers of MRSA ${ }^{5}$. The widespread and inappropriate use of antibiotics can significantly increase the risk of MRSA infection ${ }^{6}$.

Vancomycin, as the drug of choice for MRSA infection, has been reported for its resistance status to MRSA $^{3}$. The results of the nasal swab of the paramedics who served in the ICU room at Ratu Zalecha Martapura Hospital showed that there were 14 samples with the Staphylococcus aureus strain and 7 of them were Vancomycin Resistant Staphylococcus aureus strains ${ }^{7}$. Other research also found that most VRSA was found among MRSA strains ${ }^{8}$; therefore, there is a need for new and effective drugs against MRSA.

Allium sativum L. or garlic is one of the most consumed kitchen ingredients in the world. Besides being popular as a food spice, garlic is also used by many people as traditional medicine. This family of Amaryllidaceae 
is believed to have high potential as anti-microbial, anti-inflammatory, and antioxidant ${ }^{9,10}$. Crushed garlic has been shown to have broad-spectrum antibacterial activity against Gram-positive, Gram-negative bacteria and acid-fast bacteria, including Escherichia, Staphylococcus, Streptococcus, Salmonella, Klebsiella, Proteus, Mycobacteria, Vibrio, and Clostridium species $^{10,11}$. The active compound possessed by garlic also acts as an antifungal, antiprotozoal, and antiviral agent $^{12}$. Several studies have shown that garlic can be an alternative medicine for cardiovascular diseases, including hypertension and stroke. Garlic has also shown benefits in several treatments for hyperlipidemia, cancer, diabetes, and its use and safety if consumed by children. Besides smell breath, nausea, and vomiting, especially when consuming it raw, garlic has not shown any adverse side effects ${ }^{9}$.

Various studies have confirmed that the pharmacological effects of Allium sativum have the potential to be a source of new drug development. This study is expected to be able to obtain data on the potential antibacterial activity of Allium sativum against MRSA, which in the future can be used as an alternative treatment of infections due to MRSA.

\section{Materials and Methods}

\section{Bacterial used for study:}

Methicillin-Resistant Staphylococcus aureus used in this study were procured from the Laboratory of the Clinical Microbiology Department, Faculty of Medicine, Universitas Airlangga, Indonesia.

Preparation of garlic ethanol extract:

Garlic was collected from a local market in Surabaya, Indonesia. The garlic bulbs were peeled, washed, cut as thin as possible to reduce water content, and dried at room temperature for 2 days. The dried onion bulbs were crushed into a fine powder. Afterward, the powder was extracted by maceration method using $96 \%$ ethanol. Ethanol was used as an extraction material because it can dissolve secondary metabolites in garlic, selective, was not easy to grow fungi, non-toxic, and has good absorption ability ${ }^{13}$. The content of antibacterial compounds in garlic is more stable with alcohol compared to water ${ }^{14}$. The result of this extraction is a thick blackish brown extract with a distinctive pungent odor.

\section{In vitro study:}

Minimum Inhibitory Concentration (MIC)

About $2048 \mathrm{mg}$ of garlic ethanol extract were diluted with $2 \mathrm{~mL}$ of $10 \% \mathrm{DMSO}$, yielding a concentration of $1024 \mathrm{mg} / \mathrm{mL}$. Afterward, a serial dilution method was performed to obtain 9 concentrations of garlic ethanol extract, 1024, 512, 256, 128, 64, 32, 16, 8, and $4 \mathrm{mg} / \mathrm{mL}$. Mueller Hinton broth media was inserted with a bacterial suspension equivalent to a standard of $0.5 \mathrm{McF}$ arland for each test tube, then incubated at $37 \square \mathrm{C}$ for approximately 24 hours. Minimum Inhibitory Concentration (MIC) was determined by observing turbidity in the test tube visually ${ }^{15}$.

\section{Minimum Bactericidal Concentration (MBC)}

The dilution test results with various concentrations were then streaked on the nutrient agar plate's surface using the inoculation needle and incubated again for 24 hours at $37^{\circ} \mathrm{C}$. Media that showed a visualization of clarity and was not overgrown with bacteria was defined as the Minimum Bactericidal Concentration $(\mathrm{MBC})^{16}$. 


\section{Result}

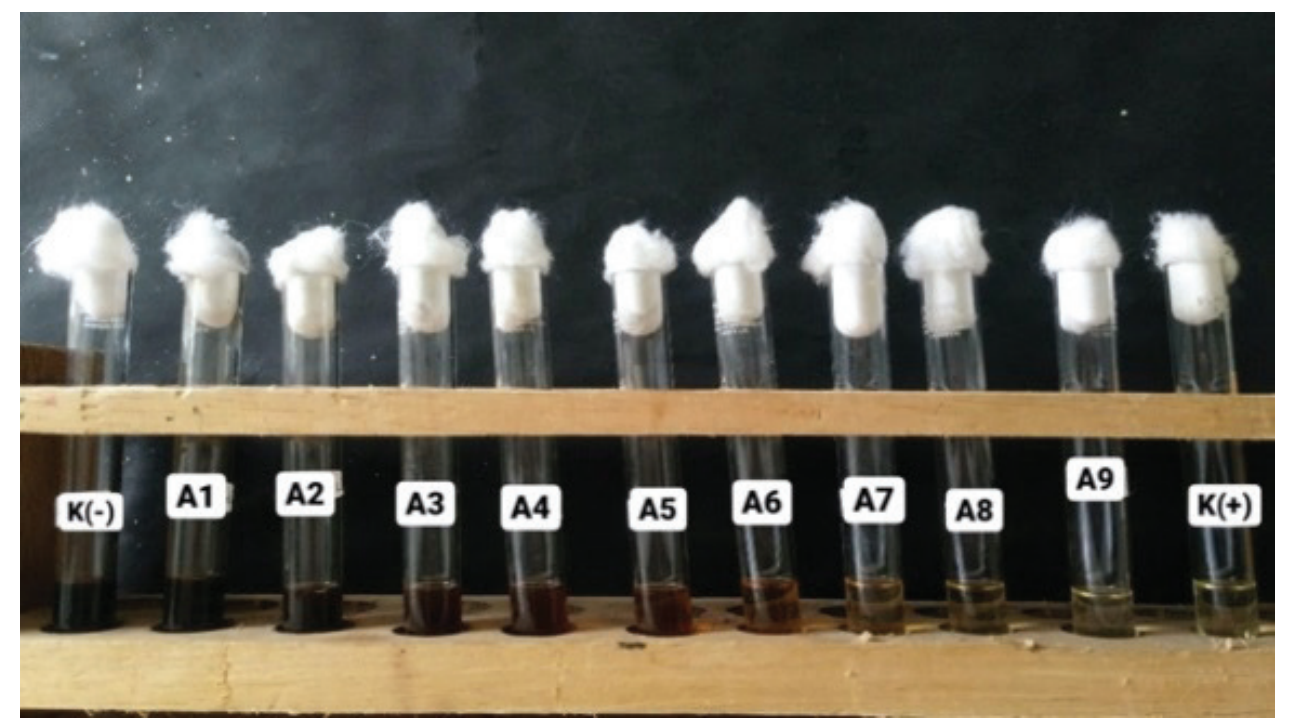

Figure 1. Dilution test tube before the incubation process

(K (-)) Negative control. Contains Mueller Hinton broth medium and garlic ethanol extract. (A1) Concentration of $1024 \mathrm{mg} / \mathrm{mL}$. (A2) Concentration of $512 \mathrm{mg} / \mathrm{mL}$. (A3) Concentration of $256 \mathrm{mg} / \mathrm{mL}$. (A4) Concentration of 128 $\mathrm{mg} / \mathrm{mL}$. (A5) Concentration of $64 \mathrm{mg} / \mathrm{mL}$. (A6) Concentration of $32 \mathrm{mg} / \mathrm{mL}$. (A7) Concentration of $16 \mathrm{mg} / \mathrm{mL}$. (A8) Concentration of $8 \mathrm{mg} / \mathrm{mL}$. (A9) Concentration of $4 \mathrm{mg} / \mathrm{mL}$. (K (+)) Positive control. Contains Mueller Hinton broth media and MRSA bacterial suspense.

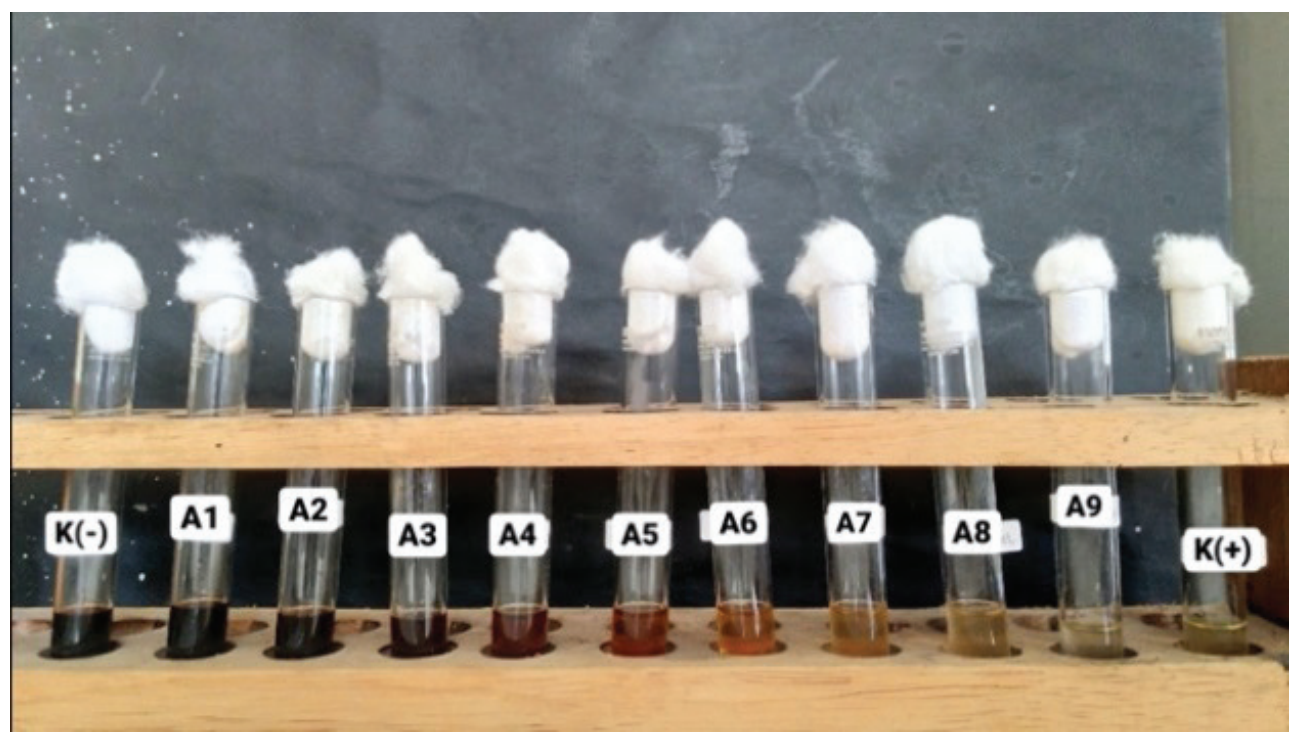

Figure 2. Dilution test tube after the incubation process

(K (-)) Negative control. Contains Mueller Hinton broth medium and garlic ethanol extract. (A1) Concentration of $1024 \mathrm{mg} / \mathrm{mL}$. (A2) Concentration of $512 \mathrm{mg} / \mathrm{mL}$. (A3) Concentration of $256 \mathrm{mg} / \mathrm{mL}$. (A4) Concentration of 128 $\mathrm{mg} / \mathrm{mL}$. (A5) Concentration of $64 \mathrm{mg} / \mathrm{mL}$. (A6) Concentration of $32 \mathrm{mg} / \mathrm{mL}$. (A7) Concentration of $16 \mathrm{mg} / \mathrm{mL}$. (A8) Concentration of $8 \mathrm{mg} / \mathrm{mL}$. (A9) Concentration of $4 \mathrm{mg} / \mathrm{mL}$. (K (+)) Positive control. Contains Mueller Hinton broth media and MRSA bacterial suspense. 
All of the samples tested showed turbidity both before and after the incubation process. It is caused by the original color of the garlic ethanol extract, which is blackish-brown. Therefore, the MIC of garlic ethanol extract could not be determined.

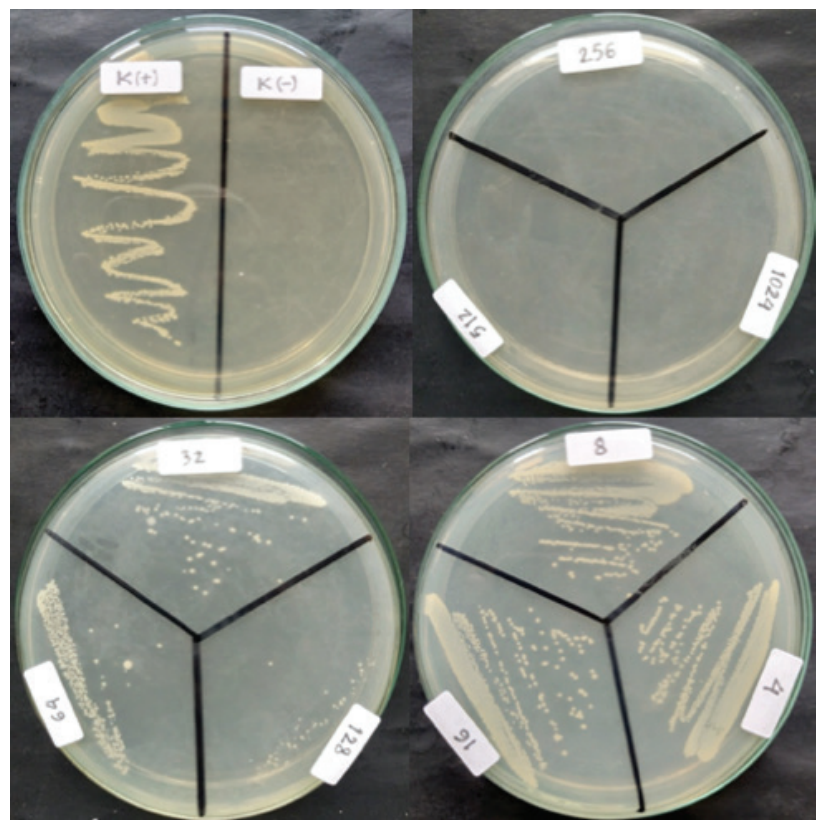

Figure 3. Results of streaking on nutrient agar plate media

After being streaked and incubated again for approximately 24 hours, K (-) or negative control showed no bacteria growing, indicating that the ethanol extract of garlic was not contaminated with bacteria, so the risk of bias could be avoided. Nutrient agar plates that have been streaked with concentrations of $4,8,16,32,64$, and $128 \mathrm{mg} / \mathrm{mL}$ indicate growing bacteria's presence. Meanwhile, the results of streaking with concentrations of 256,512 , and $1024 \mathrm{mg} / \mathrm{mL}$ showed no bacteria grow. Therefore, it can be concluded that the MBC of garlic ethanol extract is $256 \mathrm{mg} / \mathrm{mL}$.

\section{Discussion}

The garlic ethanol extract's blackish-brown color in this study might be caused by the Maillard reaction due to the lack of temperature and humidity control in the extraction process when drying at room temperature. The Maillard reaction occurs due to heating and drying, which causes a reaction between reducing sugars and amino acids in garlic. This reaction causes a change in the smell, original taste, and color of the extract ${ }^{17}$.

The antibacterial effect of garlic extract itself is played by thiosulfinate compounds, including allin, allicin, and dialyl sulfonate ${ }^{18}$. Allicin has a strong antibacterial role. The crushed garlic will produce allicin compounds, which play a role in inhibiting the synthesis of DNA, RNA, and bacterial protein ${ }^{19,20}$. Allicin's precursor is a non-proteinogenic amino acid alliin ((S-allyl-L-cysteine sulfoxide $)^{21}$. Crushed garlic activates the allinase enzyme, which then converts the alliin precursor to allyl sulfenic acid (2-propenesulfenic acid), which is unstable and highly reactive to room temperature. Then, two molecules of allyl sulfenic acid condense spontaneously with water elimination, which then forms allicin ${ }^{22,23}$. Allicin is very sensitive and unstable to heat. In ensuring the presence of allicin compounds in garlic extract, this study was conducted at room temperature ${ }^{22}$; therefore the maceration extraction method was used in this study.

The results of streaking on a nutrient agar plate in this study reveal no bacterial colonies that are growing at concentrations of 256, 512, and $1024 \mathrm{mg} /$ $\mathrm{mL}$. It indicates that the ethanol extract of garlic has bactericidal properties against MRSA. Later these results also demonstrate that its concentration is directly proportional to its antibacterial activity. The greater the concentration of the extract means, the greater the inhibition and bactericidal properties. It is marked by fewer of the colony of bacteria that grows on media with high extracts.

The bactericidal effect of garlic can be influenced by the characteristics of the bacteria itself. The antibacterial effect of the allicin compound in garlic has been shown to be three times more effective against Grampositive bacteria than Gram-negative bacteria. Lipids in the membrane of Gram-positive bacteria such as Staphylococcus aureus play a role in helping allicin compounds penetrate into bacteria, so allicin can affect the activity of bacterial RNA synthesis and protein synthesis (one of which is by exchanging disulfide compounds) by inhibiting the activity of enzyme-free thiol groups then causes damage and even death of bacteria $^{23}$. This proves that the main target of allicin compounds as antibacterials is RNA ${ }^{14,24}$. Although the molecule is unstable, allicin can easily pass through the bacterial cell membrane because of its hydrophobic nature, so it can reach the bacterial cellular compartment, which reacts quickly with the free thiol group ${ }^{25}$. 
However, Gram-negative bacteria such as E. coli which have lipid content on the membrane, are ten times higher than Staphylococcus aureus, making allicin compounds unable to reach their destination due to being trapped in the lipid content ${ }^{14}$. Allicin, which affects the enzyme thiol group's activity that acts on bacteria, makes these bacteria unable to change or modify the enzyme that plays a role, so the possibility of these bacteria being resistant to allicin and garlic is very small ${ }^{11}$.

The results of this MBC study are slightly different from several studies, including research conducted by Johnson which showed MBC garlic was $104 \mathrm{mg} / \mathrm{mL}^{26}$ and Venâncio which showed MBC of garlic against MRSA was $64 \mathrm{mg} / \mathrm{mL}^{27}$. The difference in MBC results in other studies influenced by several factors, including the location of plant growth, harvesting period, storage, and plant age. The extraction method used, the extraction tool used, the solvent used can also affect the differences in the results of each study ${ }^{28}$. In addition, different types of MRSA and different environments that MRSA develops also have different patterns of resistance and gene mutations against antibacterial compounds ${ }^{29}$.

The ability of garlic to inhibit and kill resistant bacteria such as MRSA can also be seen from other studies whose results are in line with this study ${ }^{26,27}$. Further research is needed due to differences between MIC and MBC from several other studies, further research on individual isolates or active ingredients that act as antibacterial agents in garlic, and further research on garlic's antibacterial activity with other experimental methods.

\section{Conclusion}

The MIC of ethanol extract of garlic against MRSA bacteria in this study could not be determined because the extract was turbid and blackish-brown, so the difference in turbidity in each tube with different concentrations was difficult to observe visually. The MBC of garlic ethanol extract against MRSA bacteria in this study was $256 \mathrm{mg} / \mathrm{mL}$. This indicates that the ethanol extract of garlic has antibacterial activity against MRSA bacteria.

Ethical Clearance: This experimental study protocol had been approved by the Faculty of Medicine, Universitas Airlangga, Surabaya, Indonesia.
Conflict of Interest: The authors declare that they have no conflict of interest.

Source of Funding: Self funding.

Acknowledgements: The authors would like to thank the Faculty of Medicine, Universitas Airlangga, for providing facilities needed in this experimental study.

\section{References}

1. Centers for Disease Control and Prevention. Antibiotic Resistance: A Global Threat. 2018. Available at: https://www.cdc.gov/drugresistance/ solutions-initiative/stories/ar-global-threat.html

2. WHO. Antimicrobial resistance. Global report on surveillance. Drug resistance. 2014;61(3):12-28.

3. Jawetz, Melnick and Adelberg's. Medical microbiology. $26^{\text {th }}$ ed. New York: McGraw-Hill; 2013.

4. Katzung B.G., Masters S.B., Trevor A.J. Farmakologi Dasar \& Klinik. Edisi 12. Jakarta: Penerbit Buku Kedokteran EGC; 2014. Indonesian.

5. Kuntaman K, Hadi U, Setiawan F, Koendori E B, Rusli M, Santosaningsih D, Severin J, Verbrugh H A. Prevalence of methicillin resistant staphylococcus aureus from nose and throat of patients on admission to medical wards of Dr Soetomo hospital, Surabaya, Indonesia. Southeast Asian Journal of Tropical Medicine and Public Health. 2016; 47(1):66-70.

6. Lazarus G, Audrey J. Comprehensive Assessment of Risk Factors Associated with MethicillinResistant Staphylococcus aureus (MRSA) Infection in Asia: A Systematic Review. Journal of Asian Medical Students’ Association. 2019;7(1)

7. Dwiyanti RD, Muhlisin A, Muntaha A. MRSA dan VRSA pada Paramedis RSUD Ratu Zalecha Martapura. Medical Laboratory Technology Journal. 2015; 1(1):27. Indonesian.

8. Hasan R, Acharjee M, Noor R. Prevalence of vancomycin resistant Staphylococcus aureus (VRSA) in methicillin resistant S. aureus (MRSA) strains isolated from burn wound infections. Tzu Chi Medical Journal. 2016; 28(2):49-53.

9. Khorshed AM, Obydul HM, Shahab UM. Medicinal plant Allium sativum $=$ A Review. Journal of Medicinal Plants Studies. 2016; 4(6):72-79.

10. Hussein H J, Hameed I H, Hadi M Y. A review: 
Anti-microbial, anti-inflammatory effect and cardiovascular effects of garlic: Allium sativum. Research J. Pharm. and Tech. 2017;10(11):40694078.

11. Papu Singh, Jaivir Singh, Sweta Singh, B R Singh. Medicinal value of garlic (Allium sativum L.) in human life: An overview. Greener Journal of Agricultural Sciences. 2014; 4(6): 265-280.

12. Mikaili P, Maadirad S, Moloudizargari M, Aghajanshakeri S, Sarahroodi S. Therapeutic uses and pharmacological properties of garlic, shallot, and their biologically active compounds. Iranian Journal of Basic Medical Sciences. 2013;16(10):10311048.

13. Sulistyorini A. Potensi Antioksidan dan Antijamur Ekstrak Umbi Bawang Putih (Allium sativum Linn.) Dalam Beberapa Pelarut Organik. Universitas Islam Negeri Maulana Malik Ibrahim. 2015. Indonesian. Available at : http://etheses.uinmalang.ac.id/3268/1/11620077.pdf

14. Mozaffari Nejad A S, Shabani S, Bayat M, Hosseini S E. Antibacterial effect of garlic aqueous extract on staphylococcus aureus in hamburger. Jundishapur Journal of Microbiology. 2014;7(11).

15. Jorgensen J, Pfaller M, Caroll K, Funke G, Landry M L, Richter S, Warnock D. Manual of Clinical Microbiology. 11th Ed. ASM Press. 2015.

16. Kurniati N F, Garmana A N, Aziz N. Aktivitas Antibakteri dan Antijamur Ekstrak Etanol Akar, Bunga, dan Daun Turi (Sesbania grandiflora L. Poir). Acta Pharmaceutica Indonesia. 2017;42(1):18. Indonesian.

17. Agustina E, Andiarna F, Hidayati I. Uji Aktivitas Antioksidan Ekstrak Bawang Hitam (Black Garlic) Dengan Variasi Lama Pemanasan. Al-Kauniyah: Jurnal Biologi. 2020;13(1):39-50. Indonesian.

18. Badan Pengawas Obat dan Makanan. Bawang Putih (Allium sativum L.). Jakarta: Direktorat Obat Asli Indonesia. 2016. Indonesian.

19. Cutler R R, Wilson P. Antibacterial activity of a new, stable, aqueous extract of allicin against methicillin-resistant Staphylococcus aureus. British Journal of Biomedical Science. 2004;61(2):71-74.

20. Beuchat L. Control of Foodborne Pathogens and Spoilage Microorganisms by Naturally Occurring Antimicrobials. In Microbial Food Contamination.
CRC Press. 2000.

21. Cavallito C J, Bailey J H, Buck J S. The Antibacterial Principle of Allium Sativum. III. Its Precursor and "Essential Oil of Garlic." Journal of the American Chemical Society. 1945;67(6):1032-1033.

22. Ilic D, Nikolic V, Nikolic L, Stankovic M, Stanojevic L, Cakic M. Allicin and related compounds: Biosynthesis, synthesis and pharmacological activity. Facta Universitatis - Series: Physics, Chemistry and Technology. 2011;9(1): 9-20.

23. Salehi B, Zucca P, Orhan I E, Azzini E, Adetunji C O, Mohammed S A, Banerjee S K, Sharopov F, Rigano D, Sharifi-Rad J, Armstrong L, Martorell M, Sureda A, Martins N, Selamoglu Z, Ahmad Z. Allicin and health: A comprehensive review. Trends in Food Science \& Technology. 2019;86:502-516.

24. Daka D. Antibacterial effect of garlic (Allium sativum) on Staphyloccus aureus: An in vitro study. African Journal of Biotechnology. 2011;10(4):666-669.

25. Fujisawa H, Suma K, Origuchi K, Seki T, Ariga T. Thermostability of allicin determined by chemical and biological assays. Bioscience, Biotechnology and Biochemistry. 2008;72(11):2877-2883.

26. Johnson M, Olaleye O, Kolawole O. Antimicrobial and Antioxidant Properties of Aqueous Garlic (Allium sativum) Extract against Staphylococcus aureus and Pseudomonas aeruginosa. British Microbiology Research Journal. 2016;14(1):1-11.

27. Venâncio P C, Figueroba S R, Nani B D, Nunes Ferreira L E, Muniz B V, Del Fiol F de S, Sartoratto A, Rosa E A R, Groppo F C. Antimicrobial activity of two garlic species (Allium Sativum and A. Tuberosum) against staphylococci infection. in vivo study in rats. Advanced Pharmaceutical Bulletin. 2017;7(1):115-121.

28. Departemen Kesehatan Republik Indonesia. Inventaris Tanaman Obat Indonesia (I) Jilid 1. Jakarta: Badan Penelitian dan Pengembangan. 2000. Indonesian.

29. Rahmi K A, Purwono P B, Rochmanti M. Benzalkoniumchlorideeffectivenessasadisinfectant against hospital-associated methicillin-resistant Staphylococcus aureus (HA-MRSA). Malaysian Journal of Microbiology. 2019;15(2):88-94. 